\title{
MUTISMO ANCESTRAL: A SORTE DOS ÍNDIOS
}

\author{
Luís Adriano de Souza Cezar \\ Universidade Federal do Rio Grande do Sul \\ adrnczar@gmail.com
}

RESUMEN / RESUMO / ABSTRACT

Milton Hatoum es uno de los autores más relevantes de la literatura brasileña contemporánea. En 1989, realizó su debut en el universo literario con la aclamada novela Relato de um certo Oriente. Resultado de una alta sofisticación estética y de una intrincada disposición narrativa, esa obra se distingue no solo por la fuerza de su enredo, sino también, sobre todo, porque incorpora, como elemento constituyente de los personajes y sus conflictos, el discurso histórico de una Manaus en crisis económica y cultural, después del decaimiento del Ciclo da Borracha. De tal manera, este trabajo presenta un análisis del romance, cuya referencia es la sociedad amazónica (y brasileña) a lo largo del siglo XX.

palabras clave: Milton Hatoum, Manaus, Ciclo da Borracha, decaimiento.

Milton Hatoum é um dos autores mais relevantes da literatura brasileira contemporânea. Em 1989, realizou sua estreia no universo literário com o aclamado romance Relato de um certo Oriente. Resultado de um alto refinamento estético e de um intricado arranjo narrativo, essa obra se distingue não só pela força de seu enredo, mas, sobretudo, porque incorpora, como elemento constituinte das personagens e seus conflitos, o discurso histórico de uma Manaus em crise econômica e cultural, após a decadência do Ciclo da Borracha. Dessa maneira, este trabalho apresenta uma análise do romance, cuja referência é a sociedade amazônica (e brasileira) ao longo do século $X X$.

PALAVRAS-CHAVE: Milton Hatoum, Manaus, Ciclo da Borracha, decadência.

Milton Hatoum is one of the most important authors of contemporary Brazilian literature. He made his debut in the literary world in 1989 with the acclaimed novel Relato de um Certo Oriente. This work, the result of high aesthetic refinement and an intricate narrative arrangement, is distinguished not only by the strength of its plot, but above all because it incorporates, as a constituent element of the characters and their conflicts, the historic discourse of Manaus 
during an economic and cultural crisis subsequent to the decline in the Rubber Boom. This paper therefore presents an analysis of the novel, whose frame of reference is Amazon (and Brazilian) society throughout the twentieth century.

KEYWORDS: Milton Hatoum, Manaus, Rubber Boom, decadence.

\section{DA PARIS DOS TRÓPICOS À CIDADE FLUTUANTE}

De reduzida aldéia em fins do século XIX, Manaus, já no primeiro decênio do século XX, passou a um importante centro comercial do negócio da borracha. A Paris dos Trópicos, entretanto, teve vida curta; em 1920, o Governo Federal suspendeu os incentivos que, desde o início da Primeira Guerra Mundial, tentavam debalde salvar a produção brasileira de um fracasso perante a concorrência asiática. De qualquer modo, ainda que os portos tenham esvaziado e os investimentos estrangeiros escasseado, a modernização empreendida pelo surto da borracha em toda a região amazônica, especialmente na capital amazonense, deixou marcas profundas não só no traçado urbano e nos hábitos de consumo de Manaus, mas, sobretudo, na mentalidade da pequena burguesia que se favorecera com os anos de Eldorado. A partir da crise do Ciclo da Borracha, perderam espaço (e fortuna, evidentemente) os antigos barões; em seu lugar, restaram suas mansões, seus palacetes e o símbolo máximo do fausto manauara: o Teatro Amazonas. As famílias abastadas que sobreviveram ao declínio econômico partiram, em sua maioria, para a Europa ou para o Rio de Janeiro, a fim de se afastarem do provincianismo a que estava relegada, novamente, a antiga Paris das Selvas. Esta se afundou na estagnação econômica e sua população foi incrementada por uma legião de miseráveis oriundos dos seringais abandonados que se espalhavam pelo interior amazônico.

A entrada do capital estrangeiro, além da modernização arquitetônica e urbanística, também favoreceu o fortalecimento do comércio em Manaus. A fim de suprir as necessidades de uma sociedade cada vez mais dependente do estilo de vida europeu, ou melhor, parisiense, esse setor, ao lado do setor responsável pela exportação gomífera, tornou-se fundamental para a economia manauara. Apesar da queda brusca nas atividades exportadoras, o comércio se manteve; afinal, Manaus já não era mais um acanhado reduto de pequenas casas, e sim uma cidade que fora rapidamente modernizada e invadida por imigrantes das mais diversas origens. Destes, um determinado grupo foi de extrema importância para as atividades comerciais: os árabes. 
Atraídos pelas riquezas da borracha, sírios e libaneses dedicaram-se às mais diversas modalidades do comércio no espaço amazônico: desde a regatagem pela imensidão dos rios até a administração de casas comerciais. Na Manaus pós-Ciclo da Borracha, escassearam os grandes seringalistas e exportadores, mas se mantiveram os integrantes de uma incipiente burguesia dependente de negócios exclusivamente citadinos.

A exemplo do que acontecera em outras regiões brasileiras, como os italianos em São Paulo ou os judeus em Porto Alegre ${ }^{1}$, os imigrantes árabes passaram a constituir um estrato de bastante importância econômica na sociedade manauara. Tal relevo social é abordado nos dois primeiros romances de Milton Hatoum, os quais possuem suas narrativas centradas em núcleos familiares de origem libanesa. Seja a família de Emilie, em Relato de um certo Oriente, seja a de Zana, em Dois Irmãos, ambas apresentam integrantes de uma elite local atrelada às atividades comerciais. No primeiro caso, o universo romanesco se concentra nos espaços da Parisiense, loja de gêneros que dá esteio à família, e ao casarão onde vivem os imigrantes e seus filhos. Entretanto, ainda que os relatos organizados pela narradora se refiram, majoritariamente, ao espaço privado, é no movimento das personagens as quais circulam pelo sobrado dos libaneses que se pode observar tensões sociais atinentes ao contexto histórico-social de uma Manaus de meados do século XX. Dessa maneira, a maior parte dos eventos narrados pelas diversas vozes que compõem o romance situam-se temporalmente em um período histórico posterior ao fausto gomífero, episódio cujos ganhos e perdas são fundamentais para compreender a constituição dessa Manaus moderna, dentro da qual convivem o tradicional e o moderno, o nativo e o estrangeiro e, sobretudo, as ruínas de um passado grandioso e a ânsia por um futuro que redirecione a capital amazonense para o caminho de continuidade econômica com o restante do Brasil.

A formação da Paris dos Trópicos, assim como as principais cidades ocidentais que se forjaram na virada do século XIX para o XX, é devedora da lógica urbanística de Haussmann. Essa influência europeia não é, de modo algum, exclusividade manauara ou tampouco brasileira, mas no caso de Manaus as consequências vão além da segregação espacial daqueles que excediam os já definidos lugares sociais de prestígio da modernização conservadora. $\mathrm{O}$ crescimento desse núcleo urbano à beira do rio Negro, 
mais do que afastar os pobres para as cercanias da cidade, tentou enterrar como uma chaga o que, até hoje, há de mais distintivo da região amazônica: a cultura indígena. Alijados pelos interesses do mercado internacional e, principalmente, pela mentalidade -em um arremedo de europeia- da elite manauense, os índios não compartilharam dos lucros da borracha, não se envolveram em atividades comerciais, não habitaram os casarões do centro da cidade, tampouco frequentaram as óperas do Teatro Amazonas. Dessa forma, o grupo étnico primevo da região foi de tal modo relegado que sua presença, além de desprezada socialmente, é inexistente em quase absoluto no discurso oficial a respeito dos tempos áureos de Manaus.

Antes de um percurso histórico mais aprofundado a respeito das formas de espoliação a que, desde a chegada dos primeiros portugueses à Amazônia, sempre esteve submetido o indígena, é preciso compreender a maneira por que se representa, no primeiro romance de Milton Hatoum, a estratificação social de Manaus. Este fenômeno recebeu contornos bastante acentuados com o modelo de modernização empreendido na capital amazonense durante o ápice da extração gomífera. Conservador, ele privilegiou as classes dirigentes e relegou os desvalidos ao mais severo isolamento socioespacial. Esse fundamento histórico é formalizado no romance a partir da relação estabelecida entre a família-núcleo da narrativa e as diversas personagens pobres que circundam o sobrado dos libaneses. No centro, há a matriarca Emilie, o marido e os filhos; ao redor, agregam-se as empregadas, os indígenas e os moradores de bairros pobres, como a Cidade Flutuante e os Educandos. Dessa maneira, observa-se, ao longo da narrativa, uma massa de miseráveis desassistida por iniciativas do Estado tornar-se dependente da generosidade de um grupo familiar abastado.

Durante a construção da Manaus moderna, forjaram-se -à distância do centro, naturalmente- bairros pobres para onde migraram os excedentes da reforma social empreendida na cidade. Mas a partir de 1920, ano que registra a derrocada completa dos tempos dourados do extrativismo gomífero, passa a se constituir uma surpreendente forma de agrupamento humano: a Cidade Flutuante. Formada por casas de madeira que flutuavam sobre troncos de árvores, essa aglomeração se desenvolveu de 1920 até 1967 nas superfícies do Rio Negro e de igarapés manauaras. Essa outra cidade chegou a possuir cerca de 12 mil habitantes durante a década de 1960 e contou com uma rede de serviços semelhante à que havia em terra firme: bares, restaurantes, oficinas, feiras, lojas, etc. Além disso, é preciso destacar que tal fenômeno urbano está intimamente ligado aos dois maiores marcos de entrada do capital estrangeiro 
na região amazônica: a formação da Paris dos Trópicos (1890 a 1915) e a inauguração da Zona Franca de Manaus (1967). Assim, mais uma vez, a fim de que se compreenda qualquer aspecto do processo de modernização da capital amazonense, deve-se apontar a lente de análise para esses dois polos fundamentais da história econômico-social de Manaus.

Paris dos Trópicos ou Paris das Selvas são duas expressões cunhadas durante a Belle Époque amazônica para designar a pretensiosa Manaus erigida com os excedentes financeiros da importação gomífera. Ao longo desse período de euforia econômica, houve um intenso processo migratório voltado para as capitais Manaus e Belém e para o interior amazônico, onde se situavam os seringais de extração do látex. As cidades receberam, em sua maioria, imigrantes ligados aos negócios exportadores e às empresas responsáveis pelas reformas urbanísticas. Assim, pela capital amazonense, passaram a circular cidadãos ingleses, espanhóis, portugueses, alemães, sírios, libaneses, etc. Já pelo interior, no alto dos rios, em um contato muito próximo com diversas populações indígenas, passou a viver e a trabalhar (em condições absolutamente escorchantes) uma leva gigantesca de migrantes nordestinos. Incentivados pelo Governo Federal e, sobretudo, por promessas fantasiosas de enriquecimento rápido e fácil, milhares de homens, mulheres e crianças incrementaram os grupos de seringueiros da rústica indústria extrativa. Essa massa iludida de trabalhadores nordestinos foi submetida, entre tantas formas de exploração humana, ao perverso sistema de aviamento, por conta do qual se tornavam verdadeiros escravos nas mãos dos administradores dos barracões. Dessa maneira, ainda que esses trabalhadores tenham acompanhado o Ciclo da Borracha desde os primeiros anos, a eles não coube parcela significativa dos crescentes lucros da exportação gomífera; restou, isso sim, a experiência da mais absoluta miserabilidade humana no interior dos seringais espalhados pela selva.

Despojos de uma modernização manca e aventureira, os seringueiros foram os últimos a receber as nefastas informações a respeito da bancarrota amazônica. O isolamento imposto pelos seringais e o sistema de escravização por dívidas infligiram a esses homens e mulheres modos extremamente precários de contato com a civilização. Enquanto os ingleses -que haviam construído o Manaus Harbour e se divertido nos elegantes clubes familiares da capital amazonense- retornavam para a Europa, e os grandes seringalistas, aos quais ainda restavam maneiras de escapar ao embaraço econômico, mudavam-se para o Rio de Janeiro, os trabalhadores do interior amazônico se depararam com imensos seringais abandonados, sem qualquer perspectiva de 
produtividade. Desamparados por essa nova configuração, para os sobreviventes da extração de látex não houve outra alternativa, senão recorrer a Manaus, a fim de encontrarem algum alento para sua peregrinação iniciada no sertão nordestino. Sendo assim, encetaram-se os primeiros movimentos para a construção da Cidade Flutuante.

Diante de uma cidade cujo processo modernizador contribuíra de modo decisivo para uma rígida disposição dos estratos sociais e suas respectivas posições geográficas no limite citadino, diversos seringueiros e ribeirinhos recém-chegados à principal cidade do Amazonas passaram a construir suas habitações às margens do Rio Negro. Tal escolha não é, de modo algum, aleatória, uma vez que esse grupo de migrantes possuía, no interior amazônico, formas de sobrevivência exclusivamente dependentes das águas dos rios. Deles, eram retirados o alimento; por eles, havia a navegação e a comunicação com territórios vizinhos. Não surpreende, portanto, a manutenção desse estilo de vida em Manaus, cuja formação histórico-social, apesar dos esforços urbanísticos e europeizadores da malograda Belle Époque, também debita de uma íntima relação com o rio. Desse modo, a Cidade Flutuante é um fenômeno urbano de tamanha complexidade que sua extensão e seu nível populacional são admiráveis: quase 12 mil pessoas se aglomeraram em uma área que chegou a distar 150 metros da margem.

Embora no auge de sua existência, entre as décadas de 1940 e 1960, a Cidade Flutuante tenha estabelecido um sistema de manutenção quase autossuficiente em relação a Manaus, não se deve perder de vista que esse bairro manauara guarda suas origens e seu desenvolvimento na entrada maciça de seringueiros, pescadores e ribeirinhos sem nenhuma perspectiva de trabalho ou de uma sobrevivência digna no interior amazônico. Afirmar que essa cidade possuía ferragens, oficinas mecânicas, drogarias e até mesmo consultórios médicos e dentários não é, de modo algum, realizar a defesa do seu êxito enquanto aglomerado humano. Pelo contrário, apontar para o crescimento e para as melhorias da Cidade Flutuante é, na verdade, repisar em um tema caro à literatura de Milton Hatoum: a entrada de capital estrangeiro durante o Ciclo da Borracha serviu para a construção de uma Manaus moderna em pé de igualdade com outras grandes capitais do Brasil e do mundo; entretanto, o modo como foi gerido esse excedente econômico deixou à margem dos lucros e das melhorias técnicas e culturais uma imensa parcela da população manauara. Assim, a Cidade Flutuante, longe de ser enaltecida como um paradigma do esquizofrênico jeitinho brasileiro, precisa ser compreendida como uma forma de espoliação de trabalhadores desvalidos, os quais, por 
conta do perverso descaso das políticas públicas, obrigaram-se à construção de uma comunidade famélica, desprovida de saneamento básico e transformada, ao longo do tempo, em agente poluidor do rio sobre o qual flutuava.

Em Relato de um certo Oriente, os moradores desse conglomerado são representados na sua relação de dependência com a matriarca da família-núcleo do romance. Em torno da imigrante, a fim de obterem alguma espécie de privilégio, reúnem-se alguns integrantes da Cidade Flutuante. Hakim, o filho mais velho de Emilie e um dos narradores do romance, relembra a prática da mãe em homenagem a Emir. A matriarca se deslocava anualmente até o igarapé dos Educandos, onde arremessava um retrato do jovem libanês e um vaso de flores, com o intento de exaltar a memória do irmão que se suicidara no fundo do Rio Negro. Tal atitude, repetida durante vários anos, chama a atenção dos moradores daquele bairro que se formava à beira do Negro e do igarapé; por isso, a própria Emilie torna-se alvo não só de curiosidade, mas também de idolatria pelos habitantes da Cidade Flutuante:

As dezenas de fotos de Emir serviram para Emilie colocar em prática uma promessa cumprida à risca durante boa parte de sua vida; tu deves ter reparado que, infalivelmente, a cada manhã do aniversário da morte de Emir tua avó caminhava até a Matriz e, ajoelhada, com o corpo voltado para o rio, orava os responsos de Santo Antônio; depois seguia até o cais e pedia a um catraieiro para que a conduzisse à boca do igarapé dos Educandos, onde jogava na água um vaso com flores e um retrato do irmão; esse gesto, repetido a cada ano, despertou uma certa curiosidade nos moradores da Cidade Flutuante. Alguns passaram a frequentar o sobrado para pedir conselhos a Emilie e, eventualmente, esmolas e favores (76).

Neste parágrafo, é interessante observar o movimento realizado pela personagem em destaque. Emilie, para cumprir uma promessa de verdadeiro louvor ao irmão, sai do sobrado da família e dirige-se até a praça da Matriz, em frente da qual se organizaram as primeiras habitações da Cidade Flutuante. Antes de compreender a força simbólica que esse deslocamento impele à narrativa, deve-se destacar a descrição da matriarca realizada pelo filho, narrador do fragmento:

Mas na manhã seguinte Emilie se iluminava; vestia um tailleur negro e usava o colar de pérolas contornando o decote, mas em contato com a pele. O rosto liso como o marfim era envolto pelos cabelos ondulados, e por detrás da orelha brotava a flor de jambo, de um vermelho vivo 
que repetia o vermelho dos lábios. Ao despontar assim, no vão da escada, meu pai estremecia, mordendo os beiços, talvez ressentido ou enciumado, em todo caso irrequieto e certamente fascinado com aquela visão matinal, que era a versão mais pura da beleza. Ele não estranhava a sua atitude, pois Emilie se embelezava para reverenciar um defunto, mas o fato é que, naquele dia do ano, o negro que lhe cobria o corpo era, mais que luto, luxo (89).

A última palavra, o termo que encerra esse trecho descritivo, congrega em seu significado bem mais que uma apreciação acerca da vestimenta da matriarca; revela, na verdade, o imenso contraste social existente nessa Manaus do século XX, cuja mímese, além do percurso espacial realizado pela libanesa, é a forma absolutamente desproporcional com que Emilie se veste ao se dirigir a uma das regiões mais miseráveis da cidade. De frente à Cidade Flutuante, uma mulher de postura esguia, com anel de safira e colar de pérolas, dona de uma casa de comércio e moradora de um sobrado no centro, atira flores e um retrato ao rio. Após esse rito, ela ainda recebe em sua casa mendigos, curumins e doentes (em uma fila, a cada ano maior) para lhes oferecer guloseimas e -mais importante- ajuda e proteção. Esse luxo, portanto, a que remete Hakim, é a insígnia desse grupo manauara que não apenas mora distante dos miseráveis, mas, sobretudo, veste-se e age de modo distinto aos habitantes dos Educandos, da Cidade Flutuante e de tantos outros bairros que proliferaram à revelia dos projetos urbanísticos do início do século.

Como próprio Hakim defende ao longo do romance, os presentes, as esmolas, as eventuais ajudas e favores não significam, em essência, uma generosidade louvável de Emilie. Ao passo que no universo público a imigrante libanesa "se empenhava para que nada faltasse aos moradores da Cidade Flutuante" (88), no privado, no interior do sobrado comandado por ela, pouco havia da "mãe de todos" (89). No preparo do festivo dia em que Emilie celebrava a memória do irmão, ajudando aos miseráveis de Manaus, colaboravam as amigas Hindié, Mentaha e Yasmine, além das empregadas e dos filhos e parentes destas. Aqui, avulta a perversidade que impregna as relações estabelecidas entre o senhor e os seus fâmulos na sociedade manauara em realce. Nenhuma das empregadas que passaram pelo sobrado de Emilie receberam honorários; além do mais, ainda foram vítimas dos abusos dos gêmeos da casa, os quais contavam com a conivência materna, mais interessada em proteger os filhos que dar ouvidos a "sirigaitas" (77).

A forma de interação entre a matriarca libanesa e os desvalidos manauaras que circundam o sobrado revela, apesar de ocultada por uma singela e 
despretensiosa filantropia, a reiteração do poder de um estrato social sobre outro. Ao presentear, Emilie não está propriamente se doando à leva de miseráveis, e sim reafirmando a sua superioridade econômica e social. Todos aqueles homens, mulheres e crianças, constrangidos por um contexto de estagnação dos negócios extrativistas, não possuem alternativa diferente, senão recorrer às esmolas advindas de um membro da elite comercial que se formou graças à transformação da Manaus aldeia em Manaus moderna. Em um sistema truncado, dentro do qual concorrem seringueiros recém-chegados dos seringais abandonados do interior, caboclos, indígenas, mendigos, crianças órfãs, todos, evidentemente, relegados às posições e às moradias mais desfavorecidas na geografia da cidade, passam a depender do assistencialismo de alguém que ocupa uma posição hierárquica, impudentemente, acima. Em troca, como forma de agradecimento à bondade da libanesa, os mais variados presentes:

Eram objetos, animais e plantas originários dos quatro cantos da Amazônia: pássaros e répteis vivos e empalhados, o precioso rouxinol do rio Negro, mudas de trepadeiras, samambaias e palmeiras, peixinhos fosforescentes, piranhas embalsamadas, e até mesmo a réplica fiel de um remo sagrado que conta a história de uma tribo indígena (89).

Pelo que se vê, todas as ofertas recebidas por Emilie são marcadas seja pela cultura, seja pela natureza amazônicas. Em primeiro plano, essa retribuição - desnecessária, mas compreensível se levada em consideração a atitude de contornos paternalistas da imigrante libanesa- nada mais é do que o pouco que essas pessoas podem oferecer: frutas, plantas, caças, objetos pessoais, tudo carregado de uma ânsia por agradar à mãe de todos. Observados, entretanto, com mais vagar, esses presentes podem ser compreendidos como uma forma de entrega simbólica dos elementos constituintes da identidade desses agraciados. É o povo amazônico, o homem de sentimento arraigado aos rios e à selva, um dos últimos resistentes à urbanização, realizando a própria amputação cultural no interior da cidade. Este espaço, que se impôs de tal modo que exigiu a migração para as suas fronteiras, achata indígenas, caboclos, nordestinos em uma mesma massa de miseráveis sujeitos aos desmandos da classe abastada; e se tiverem sorte, ganharão esmolas e até favores.

Os presentes foram tantos e tão variados que Emilie necessitou de um amanuense para organizá-los. Neste ponto do romance, deve-se enfatizar o alcance da influência da matriarca na rotina de Manaus. A fila diante do sobrado é enorme, a cada ano, ela é incrementada por mais homens e mulheres; e estes fazem de Emilie um verdadeiro ídolo, o qual recebe beijos 
na mão esquerda e oferta, com a direita, "comida à base de farinha de trigo integral" (90). Não seria absurdo supor que fora a própria Emilie quem abriu os caminhos para que Expedito Socorro se tornasse empregado no correio. Afinal, que chances de ascensão social o sobrinho de uma índia teria, senão protegido e favorecido por alguém do calibre da libanesa? Manaus, apesar da recente urbanização a que fora submetida, não havia se livrado dos ranços provinciais, e o modelo da família patriarcal, constritiva e com um amplo círculo de poder e privilégios, ainda dominava na mentalidade dos grupos mais distintos da cidade. Dessa maneira, Emilie encarna os sentidos mais perversos das relações de cordialidade ${ }^{2}$ impingidos por essa velha ordem familiar.

\section{ANASTÁCIA SOCORRO: TRISTE AGORA, LOGO DESESPERADA, AMANHÃ RESIGNADA}

Além dos moradores da Cidade Flutuante, dos mendigos e de tantos outros miseráveis que esperam alguma caridade de Emilie, outro importante grupo social também está à mercê dessa mesma proteção: os indígenas. Assim como os outros, os índios citadinos pertencem a uma faixa da esfera social eminentemente ligada aos desígnios dos membros de uma faixa superior. Desse modo, na Manaus pós-Ciclo da Borracha, submetida à mais absoluta imobilidade econômica, a estratificação social que se constituíra e se fortalecera com os anos de ouro da extração gomífera solidificou algumas posições as quais são representadas ao longo da narrativa.

Tal representação preserva os aspectos nefastos da interação entre membros pertencentes a esferas opostas. Por exemplo, a família de imigrantes libaneses, cujo posicionamento é o de uma elite local ligada aos negócios do comércio, e índios urbanizados (especialmente mulheres, incorporadas ao trabalho doméstico) que, a fim de não se submeterem à miserabilidade da mendicância, sujeitam-se aos caprichos e aos disparates desse grupo familiar. Assim sendo,

2 Neste passo, é preciso esclarecer que a cordialidade a que se refere neste trabalho está de acordo com a chave interpretativa proposta por Sérgio Buarque de Holanda, em Raizes do Brasil. No quinto capítulo dessa obra, cujo título é "O homem cordial", o autor desenvolve um conceito fundamental para compreender a influência do modelo de família patriarcal na sociedade brasileira. 
embora também se formalize o vínculo dos moradores da Cidade Flutuante com o sobrado dos libaneses, é justamente na relação estabelecida entre Emilie (e seus filhos) e Anastácia Socorro (além dos filhos e afilhados) em que se assiste a um dos capítulos mais cruéis da narrativa, a qual guarda origens, naturalmente, na realidade social de uma Manaus de meados do século XX.

A fim de realizar o diálogo desse relacionamento tão marcado pela perversidade com o conceito desenvolvido por Sérgio Buarque de Holanda, é preciso equacionar as especificidades da índia Anastácia Socorro, enquanto pertencente a um grupo étnico espoliado e perseguido desde o princípio da invasão portuguesa em terras amazônicas. Portanto, compreender a crueldade a que está constrangida a empregada doméstica do sobrado dos libaneses exige um movimento de análise histórica, o qual situará Anastácia em uma linha sucessória de mulheres indígenas que, desde a sociedade colonial, foram inseridas no convívio com a civilização como força de trabalho ou potencial reprodutivo.

Em um breve ensaio, intitulado Laços de parentesco: ficção e antropologia, Milton Hatoum comenta a constituição de Domingas, uma das personagens de seu segundo romance, Dois Irmãos. Indígena, ela é incorporada à família de Zana ainda jovem, após a esposa de Halim doar algumas mesas e cadeiras para as religiosas que tomavam conta dessa e de outras crianças órfãs e oriundas do interior amazônico. Evidentemente, Domingas ingressa na vida dos imigrantes libaneses para tomar conta do trabalho doméstico; serviçal, destina-se a ela uma extenuante rotina de afazeres no sobrado dos patrões. Segundo o autor, a gênese dessa personagem remonta, (além de duas viagens realizadas em sua juventude ao Alto Rio Negro, das quais retornou deprimido por conta da condição de exploração a que os índios da região, abandonados pelo poder público, estavam submetidos nas mãos de comerciantes, militares e religiosos), às experiências vividas na própria capital amazonense, onde testemunhou cenas de humilhação e resignação em várias casas; vidas de sofrimento de mulheres dedicadas à patroa e à família. Desse modo, Hatoum justifica a construção de Domingas por meio de uma "adesão afetiva a pessoas desgarradas de seus povoados, que moravam e trabalhavam em Manaus" (Hatoum, Laços de parentesco: ficção e antropologia 84).

Em acréscimo a isso, o autor amazonense realiza o ponto de contato de Domingas com Félicité, personagem de Flaubert, também uma empregada doméstica marcada pelo abuso e pela espoliação. Sob o ponto de vista da literatura brasileira, a mãe de Nael é inserida em uma linha de personagens femininas pobres e humilhadas, na qual antecedem a costureira de Memórias 
Póstumas de Brás Cubas, Dona Plácida, e a migrante nordestina de $A$ hora da estrela, Macabéa. Para Hatoum, essas mulheres comovem o leitor e espelham mazelas ainda existentes na sociedade brasileira. Assim sendo, lançando sua lente de análise para região amazônica, a abordagem de Milton Hatoum é "uma tentativa de reparação a tantas Domingas exaustas e mal pagas da minha infância e juventude amazonense, fonte primária da minha experiência, de que depende a imaginação romanesca" (Hatoum, Laços de parentesco: ficção e antropologia 87).

Embora Milton Hatoum, no ensaio em destaque, enfatize apenas Domingas, é preciso inserir outra personagem nesse grupo de mulheres pobres - a empregada de Relato de um certo Oriente, Anastácia Socorro. De modo semelhante à serviçal do segundo romance, Anastácia também é de origem indígena e sofre os mesmos abusos físicos e sexuais no interior de um sobrado de imigrantes libaneses. Nessa série, ainda se podem juntar as empregadas Naiá, de Cinzas do Norte, e Florita, de Órfãos do Eldorado. Dessa maneira, na obra romanesca de Hatoum, evidencia-se a representação -ao lado de outros naturalmente- de um grupo social determinado: índias desgarradas de suas localidades de origem e aculturadas na capital a fim de que se tornem empregadas domésticas em casas de pessoas socialmente privilegiadas. A respeito dessa sucessão de personagens, cuja constituição guarda procedência em um mesmo fundamento histórico-social, deve-se notar que, entre as quatro, Anastácia Socorro é a que menos circula entre os patrões; sua influência na vida da família a que serve, se comparada, por exemplo, à de Naiá, a qual aconselha e repreende a patroa Alícia, é absolutamente nula. Portanto, sobre a primeira serviçal representada incide uma perversidade nas relações com os empregadores muito mais aguda do que a observada nos romances subsequentes.

A respeito de Memórias Póstumas de Brás Cubas, o crítico literário Roberto Schwarz afirma que os episódios envolvendo Eugênia e Dona Plácida ganham realce em virtude da "profundidade com que inventam [...] as consequências que a estrutura social brasileira trazia aos desfavorecidos" (111). Em sentido análogo, as empregadas domésticas construídas pela escrita de Milton Hatoum possuem correspondência com a sociedade manauara do século XX. Desamparada por iniciativas do Estado, as quais, entretanto, subvencionam o patronato extrativista (especialmente o ligado às atividades de extração gomífera), a população da Amazônia é submetida a condições de intensa miséria, sem alternativas de inserção em formas satisfatórias de produção econômica. De acordo com Darcy Ribeiro, essa situação se agrava 
em períodos letárgicos da economia amazonense, como o que se sucedeu ao fracassado empreendimento do Ciclo da Borracha. Constituem o grosso dessa população miserável índios, seringueiros, caboclos e ribeirinhos que, desprovidos de perspectivas positivas no interior amazônico, adensam os subúrbios das principais capitais do Norte, Belém e Manaus. Nesta, formaram-se diversas aglomerações humanas marcadas pelas mais torpes condições de vida, como a já citada Cidade Flutuante. Além desses bairros, outra consequência do embaraço econômico é a urbanização de contingentes indígenas, aos quais não restam opções de trabalho muito diversificadas: artesanato ou trabalho doméstico. Correspondem, portanto, a este grupo as personagens domésticas dos romances de Milton Hatoum, as quais possuem trajetórias de vida ao longo das narrativas bastante semelhantes.

A inserção compulsória do indígena amazonense à civilização remonta à chegada dos portugueses na região por volta do século XVII. No delta do Amazonas, a fim de expulsar franceses, ingleses e holandeses que ameaçavam sua soberania, a antiga Coroa construiu fortes de proteção. Estes se tornaram núcleos de ocupação que rapidamente perceberam as lucrativas possibilidades exportadoras das drogas da mata. Em um ambiente absolutamente inóspito ao conhecimento e ao modo de vida português, a opção mais óbvia foi recorrer à mão de obra indígena. A população autóctone foi incorporada de duas maneiras ao empreendimento de busca por especiarias no interior amazônico: a primeira delas -a mais recorrente- foi a escravização de tribos inteiras; a segunda, por sua vez, representa a inclusão do indígena na lógica mercantilista -em troca de produtos trazidos da Europa pelos portugueses, os índios, transformados em consumidores, trabalhavam na floresta. Inicia, dessa maneira, o extermínio de estilos primitivos de vida em tribos que floresciam de forma grandiosa:

Toda a área era ocupada, originalmente, por tribos indígenas de adaptação especializada à floresta tropical. A maioria delas dominava as técnicas de lavoura praticadas pelos grupos Tupi do litoral atlântico, com que se depararam os descobridores. Em algumas várzeas e manchas de terra de excepcional fertilidade e de fácil provimento alimentar, através da caça e da pesca, floresceram culturas indígenas de mais alto nível tecnológico, como as de Marajó e de Tapajós, que podiam manter aldeamentos com alguns milhares de habitantes (Ribeiro 279).

Apesar do poderio português, os indígenas reagiram às tentativas de escravização, fugindo para o interior da mata. Por essa razão, surgem as 
tropas de resgate; solução cara e precária, logo foi substituída pela formação de núcleos missionários, em que os índios apresados dedicavam-se ao serviço com os padres, à edificação de obras públicas e à coleta de drogas da mata. Nesses aldeamentos, liderados por jesuítas, carmelitas ou franciscanos, índios das mais diversas matrizes eram reunidos em único espaço de convivência. Do ponto de vista cultural, essa homogeneização foi devastadora, já que línguas, crenças e modos de vida distintos cederam ao enquadramento do cativador. Dessa maneira, pode-se afirmar que houve a tupinização dos indígenas amazônicos -a língua e o estilo de vida dos Tupis, com quem os portugueses interagiram de tal forma que sincretizaram mestiços chamados de mamelucos ou neobrasileiros, foram impostos pelo colonizador cujo ponto de vista, quando chegou à Amazônia, era duas vezes influenciado: pela formação européia e pelo intenso contato com o indígena litorâneo.

$\mathrm{O}$ vulto das populações, a fartura alimentar e a alegria de viver a que remetem os primeiros cronistas da ocupação portuguesa logo foram substituídos pelo trabalho forçado, em que o índigena, segundo as expressões cunhadas por Ribeiro, tornou-se: índio-remo, índio-piloto, índio-bússola. Transmissor dos modos tradicionais de sobrevivência, o autóctone transformou-se no saber, no nervo e no músculo do colonizador; espantado, padre Antônio Vieira, no século XVII, contabiliza 2 milhões de índios dizimados em apenas uma década:

Essas condições de exploração provocaram o extermínio das populações aborígenes e criaram um ambiente de extrema tensão interétnica. Mas a ordem social pôde ser mantida graças à implantação e atuação, ao longo de séculos, do mais vasto aparelho de destribalização e de conscrição violenta de índios ao trabalho (Ribeiro 287-288).

O vasto aparelho de destribalização a que remete Darcy Ribeiro tem a ver, sobretudo, com a homogeneização ocorrida no interior dos aldeamentosreduções. O tupi, língua dos índios litorâneos, contribuiu para a formação de uma língua geral, denominada, na região amazônica, nhengatu -falada por índios genéricos, sem cultura e identidade específicas. Com a formação e o desenvolvimento das cidades na região, os indígenas também foram fazendo parte do contexto urbano, mas sempre relegados a posições desfavorecidas socialmente; de tal modo que no universo colonial, conforme recorda Araújo, os índios eram considerados súditos inferiores da Coroa. Além do mais, nesse contexto, 
uma inversão quanto aos papéis tradicionalmente executados [nas comunidades indígenas] se opera, quando os homens são lançados no trabalho agrícola, tarefa social das mulheres, e estas são desviadas para o serviço doméstico nas casas dos colonizadores, tornando-se suas escravas e sendo submetidas aos seus caprichos sexuais (Miranda 7).

Compulsoriamente utilizados como mão de obra na conquista da Amazônia, homens, mulheres e crianças indígenas representam o alicerce para a vida social desse período. Às índias, entretanto, não couberam apenas os papéis de amas de leite e farinheiras da Coroa (conforme promulgado pelo Regimento das Missões de 1686), mas também foram impelidos a elas casamentos forçados com colonos. Estes, desde os primeiros anos da ocupação portuguesa, exploraram indiscriminadamente as mulheres indígenas, dando início a uma prática que criou profundas raízes na mentalidade e, sobretudo, nos hábitos masculinos. Durante o auge do Ciclo da Borracha, por exemplo, intensificou-se o comércio de mulheres indígenas para os seringais; uma vez que estes eram muitos e bastante povoados, a índia se tornou objeto escasso. Reificada, a mulher era mercadoria valiosa na perversa economia do aviamento. Por conta disso, as indígenas passaram a ser capturadas a fim de servir regiões como a do Alto Juruá, no Amazonas; caso resistissem, eram amarradas e amordaçadas -em uma forma de tortura conhecida por amansamento.

Além de utilizadas como potencial reprodutivo, já que a Coroa, pelo bem do povoamento, permitiu a reprodução dos colonos com mulheres indígenas, estas também foram incorporadas à sociedade colonial como força de trabalho doméstico. Assim, desde os mais remotos tempos da ocupação portuguesa em terras amazônicas, a índia sempre esteve muito próxima da rotina e da casa dos colonizadores, prestando-lhes inumeráveis favores (sexuais, mormente). Solidificados os costumes, a instituição do compadrio passou a dar suporte às relações sociais da Amazônia. Essa forma específica de interação entre as classes, comum ao interior e às capitais, possuía como esteio o modelo de família patriarcal, cujos privilégios se estendiam de forma ampla e abundante. Líderes políticos e membros do patronato extrativista e comercial apadrinhavam meninos e meninas pobres do interior (indígenas, em sua maioria) para fazê-los empregados de seus palacetes e sobrados nas capitais Belém e Manaus. Crias da família, essas crianças assumiam uma posição ambígua: tanto poderiam ser vistas como filhos de criação, quanto como serviçais da casa. Evidentemente, o segundo ponto de vista se sobrepunha, e, para os filhos dessas famílias abastadas, as empregadas não passavam de mulheres-escarradeiras: prestavam-se à iniciação sexual e a abusos das 
mais diversas naturezas. Subjugadas ao capricho dos patrões, a culpa da gravidez geralmente lhes era atribuída; caso tivessem sorte, poderiam criar os seus -exclusivamente seus- filhos malditos. Constitui-se, desse modo, uma verdadeira ancestralidade de filhos enjeitados, cuja marca é o silêncio da origem e da submissão.

Justamente desse fundamento histórico se vale a construção das empregadas domésticas de Hatoum. Anastácia Socorro, Domingas, Naiá, Florita, todas carregam em sua gênese as marcas de desmando e espoliação a que as mulheres indígenas, desde os tempos coloniais, foram submetidas no interior de casas abastadas de Manaus. No contexto da produção romanesca de Milton Hatoum, Relato de um certo Oriente, além de inaugurar essa linha sucessória de personagens femininas pobres e humilhadas, também apresenta uma "periferia de agregados" (Cerqueira e Rezende) que buscam alguma forma de privilégio em torno da matriarca libanesa (como representantes desse grupo, destacam-se, sobremaneira, os moradores da Cidade Flutuante e de outros bairros miseráveis da capital amazonense). Dessa maneira, a relação de Emilie com os desvalidos que a circundam assume um sentido autolegitimatório: estes a veneram, porque necessitam de sua proteção; aquela os acolhe, porque isso renova e expande seu poder.

No alcance da influência da matriarca libanesa, confundem-se os limites do ambiente público e do privado. Em torno da mãe de todos, agregam-se os desvalidos de uma cidade paralisada economicamente; apesar desse epíteto, sob o manto da atitude afetuosa conquistada pelo convívio quase familiar entre Emilie e os agregados, movimenta-se uma espécie de civilidade a qual, na esteira do argumento de Holanda, "pode exprimir-se em mandamentos e sentenças" (147). Sendo assim, a matriarca leva à esfera da intimidade relações que, à primeira vista, não deveriam se pautar dessa maneira e, com isso, alarga o alcance da sua importância na sociedade manauara (lembrando que, mesmo na velhice, a libanesa continua influente, afinal, por meio de bilhetes entregues à polícia, solta pequenos infratores da cadeia); todavia, o reverso dessa prática tão acolhedora (da qual se favoreceu, em certa medida, a narradora do romance e seu irmão) é o tratamento dispensado, especialmente, a Anastácia Socorro: submetida a uma cordialidade que a sufoca no interior do sobrado sem o direito de experimentar uma comida digna ou de receber um mísero salário. 


\section{EMILIE: CORDIALMENTE PERVERSA}

Nessa dialética da cordialidade, a imigrante libanesa possui um comportamento marcadamente ambíguo. Na frente do sobrado, auxiliada pelo amanuense Expedito Socorro, a matriarca realiza ofertas aos pobres; por tal razão, é chamada mãe de todos. No interior, entretanto, esforça-se a fim de manter uma relação, no mínimo, afetuosa com a empregada Anastácia Socorro, tia de Expedito. A dona de casa respeitada por diversos moradores manauaras e reconhecidamente generosa é a mesma que "resmungava porque Anastácia comia 'como uma anta'" (76). Assim sendo, das práticas sociais empreendidas por Emilie pode-se compreender as duas faces da convivência com os agregados: de um lado, a oferenda, como forma de garantir a dependência; de outro, o escárnio e a humilhação, modos de açoitar e de reiterar o privilégio.

O sentido dessa convivência cruel e absolutamente corriqueira no contexto manauara aprofunda-se no relacionamento estabelecido entre os membros da família libanesa (especialmente Emilie e seus filhos inomináveis) e as empregadas da casa (com maior ênfase para Anastácia Socorro). Dando continuidade a um costume já bastante difundido entre os homens pertencentes a estratos privilegiados da sociedade de Manaus, os gêmeos, cujos nomes não são revelados ao longo da narrativa, se prevalecem das domésticas do sobrado e, ao mesmo tempo, beneficiam-se da proteção materna. Sobre esse ponto, é importante destacar a perspectiva de Hakim -irmão mais velho, de modo algum afeito a essas práticas:

[...] meus irmãos abusavam como podiam das empregadas, que às vezes entravam num dia e saíam no outro, marcadas pela violência física e moral. A única que durou foi Anastácia Socorro, porque suportava tudo e fisicamente era pouco atraente. Quantas vezes ela ouvia, resignada, as agressões de uns e de outros, só pelo fato de reclamar, entre murmúrios, que não tinha paciência para preparar o café-da-manhã cada vez que alguém acordava, já no meio do dia. Vozes ríspidas, injúrias e bofetadas também participavam desse teatro cruel no interior do sobrado (76).

Voz crítica à conduta dos gêmeos, o primeiro filho de Emilie, além de trazer à tona de modo genérico a forma com que os irmãos tratavam as mulheres de estrato inferior, ainda relata um evento pontual e extremamente profícuo para compreender o alcance desses desmandos. Embora sempre descrito como um homem silencioso, ponderado e de ação restrita aos limites da Parisiense, 
certa feita, o marido de Emilie ingressa furiosamente no interior do sobrado, de cinturão em punho, cobrando a responsabilidade dos gêmeos pelo filho de uma mulher desconhecida. Encolerizado, "gritou, entre pontapés e murros na porta, que um filho seu não pode escarrar como um animal dentro do corpo de uma mulher" (77). Neste ponto, mostra-se importante destacar o uso do verbo escarrar, já que este termo resume em seu significado o valor atribuído às mulheres que apareciam na Parisiense exigindo a paternidade de seus rebentos. Elas são de tal modo depreciadas que, ao invocar o desrespeito dos gêmeos a Deus, o marido de Emilie recebe uma resposta definidora do caráter das relações sociais constituídas entre homens abastados e mulheres pobres no contexto manauara: "- Deus? - contra-atacou Emilie. - Tu achas que as caboclas olham para o céu e pensam em Deus? São umas sirigaitas, umas espevitadas que se esfregam no mato com qualquer um e correm aqui para mendigar leite e uns trocados" (77-78).

Este pequeno excerto revela de maneira incisiva o nefasto tratamento a que estão subordinados os desvalidos de Manaus: índios, caboclos, ribeirinhos, seringueiros, enfim, toda uma sorte de homens e mulheres que a modernização da Belle Époque intentou dissimular. Entretanto, os mal fadados rumos econômicos da capital amazonense obrigaram-na a acolher esse enorme excedente humano. Desse grupo de miseráveis, recebem destaque, por sua condição ainda mais despojada de qualquer dignidade humana, as mulheres; exploradas pela posição social rebaixada e, sobretudo, pelo gênero, a elas restou o papel de escravas: seja domésticas, seja sexuais. A indignação de Emilie possui um fundamento de classe manifesto: na lógica da matriarca, representante do grupo dirigente, o sexo -índice mais cortante da dominação masculina- é um pretexto utilizado por mulheres interessadas em se valer das posses da família. A responsabilidade dos filhos não se exime somente porque o amor dessa mãe é incondicional e cegamente devotado aos seus, mas, sobretudo, porque as tais caboclas são sujeitos pertencentes a setores desprestigiados socialmente. Dessa maneira, em uma sociedade ainda bastante enraizada em costumes herdados pelos ditames coloniais, que desde os primeiros anos submeteram a mulher indígena (e também a mestiça) ao sentimento colonizador de pertença, não espanta que a matriarca (ainda que mulher, mas mulher proprietária, estrangeira e católica fervorosa) julgue os filhos segundo os critérios do espaço privado -a cordialidade das relações enseja esse procedimento em tudo injusto e perverso.

A crueldade se aprofunda ainda mais no relacionamento da índia Anastácia Socorro com Emilie e os filhos inomináveis. A razão por que a permanência 
da empregada foi tão longa no seio da família libanesa indigna na mesma medida em que comove. Ela não foi abusada pelos gêmeos, porque era feia; não havia respeito ou consideração, e sim um desprezo de tal modo demasiado que nem mesmo para o escarro sexual Anastácia servia. A doméstica não abandonou o convívio com os imigrantes, porque era forte; provavelmente, após uma vida pregressa de embaraços, já chegara ao sobrado resistente a agressões físicas. A feiura e o lombo curtido não são atributos aos quais se deva dedicar louvores; ironicamente, para a serviçal de Emilie, são eles que lhe deram amparo - parece que a humilhação consagrada a essa mulher nasce de todos os lados.

\section{A ANCESTRALIDADE DA SUBMISSÃO}

Na fatura do romance, Anastácia Socorro é uma personagem cuja concepção corresponde à estrutura social manauara. Em uma Manaus de meados de século XX, submetida a uma severa estagnação econômica após a crise da borracha, os estratos da sociedade já não contam com os poderosos barões da extração gomífera; todavia, uma imensa leva de miseráveis, para os quais as alternativas de sobrevivência no interior eram as mais custosas, buscou a cidade mais importante da região a fim de melhores condições de vida. Desse movimento de urbanização caótica, nasceu, conforme já observado, a Cidade Flutuante, a qual é representada no romance na forma de dependência estabelecida por alguns moradores com a matriarca libanesa. Percurso semelhante, mas de origens bastante recuadas no tempo, é o ingresso de indígenas no convívio urbano. Incorporada à civilização compulsoriamente, quer como presas das tropas de resgate, quer como catecúmenos dos núcleos missionários, a população de índios amazônicos, desde os primeiros tempos da ocupação portuguesa, sempre esteve -embora alguns membros mais arredios fugissem para a mata e para o alto dos rios-muito próxima dos colonizadores. Assim sendo, quando se trata desse grupo de indígenas urbanizados, cujo aumento também está ligado ao auge do Ciclo da Borracha, período em que se impôs sobremaneira a lógica de modernização calcada na tecnologia e na urbanização, pode-se afirmar uma verdadeira ancestralidade na sujeição às famílias pertencentes a esferas privilegiadas da sociedade manauara.

Tal linha de submissão é formalizada na narrativa a partir dos indígenas que circundam o sobrado dos libaneses. A matriarca não era servida apenas por Anastácia, mas também pelos filhos, sobrinhos e afilhados da índia. Nessa 
conta, ainda podem ser considerados o tio de Anastácia, Lobato Naturidade, responsável pelo resgate de Emir; Expedito Socorro, o jovem amanuense; e uma das filhas de Anastácia, empregada com quem a narradora se depara ao acordar em frente à casa da mãe na volta a Manaus. Dessa maneira, a árvore genealógica indígena, a qual se mostra dependente dos desígnios da libanesa e seus familiares, constitui-se da seguinte forma: Lobato Naturidade é o mais velho; este é tio de Anastácia Socorro, a qual é mãe dos fâmulos que, nos fins de semana, ajudam nas tarefas domésticas do sobrado; além disso, há Expedito e a empregada que desperta a narradora - essa última serviçal é um dos citados fâmulos, já adulto, evidentemente.

$\mathrm{O}$ vínculo de Lobato Naturidade com a matriarca não é, à primeira vista, pautado pela sujeição; afinal, Hakim é categórico ao afirmar que "Emilie tratava-o com um respeito que aspirava à veneração" (83). Essa deferência foi moldada logo após o suicídio de Emir; na confusão para resgatar e identificar o cadáver do jovem libanês, o misterioso indígena, de modo bastante rápido e eficaz, encontrou o corpo do suicida e trouxe alívio à irmã. Daí em diante, Emilie dedicou a ele uma "amizade [...] louvada por uns e tripudiada por outros" (84). E é justamente nesse ponto em que residem os traços definidores da superioridade hierárquica da libanesa. Sob o manto cordial da "lhaneza no trato, a hospitalidade, a generosidade" (Holanda 146), a civilidade da matriarca venera o velho Lobato; entretanto, também carrega consigo o inocultável germe da dominação. Entre Hector Dorado, Esmeralda, Américo, dr. Royal, Shalom Benemou e a esposa (vizinhos e amigos da família de Emilie), a circulação de Naturidade como um curandeiro eficiente não depende da própria competência ou da fama que o precede, e sim do prestígio que lhe é conferido pela matriarca - a indicação e o endosso da libanesa são capazes de quebrar as barreiras impostas a um sujeito marcado por injúrias e "notícias difamatórias" (85). Tal resistência se origina do lugar social e, sobretudo, do ambiente cultural a que pertence essa personagem indígena:

[...] o que mais irritava as pessoas era a vida errante de Lobato, a inexistência de uma moradia fixa. Cercado de urubus, viam-no ingressar na carcaça de um barco meio soterrado no mar de dejetos à beira de um igarapé; outros juravam que ele frequentava sórdidas palafitas, cujas paredes estavam cobertas de imagens de santos estranhos, com olhares não se sabe de embriaguez ou loucura; num recanto próximo ao casebre, um círculo de pontos luminosos brotava do breu da noite e aclarava garrafas de cachaça e galinhas mortas entre montículos de medalhas profanas (85-86). 
Neste passo, o que o narrador Hakim evidencia é bem mais do que temor à medicina de Lobato ou às lendas originadas pelo mistério em torno do qual vive esse homem, e sim o preconceito de uma população que execra o conhecimento, a cultura e os modos de vida do grupo étnico autóctone. As personagens citadas, para quem Lobato prestou algum serviço medicinal ou de resgate a mortos e desaparecidos, são todas elas estrangeiras por nascença ou ascendência. Isto é, embora Manaus seja uma cidade cuja formação depende essencialmente da tradição nativa (dentro da qual se insere a importância dos rios, da floresta e das formas de adaptação indígenas), há uma evidente sobreposição simbólica do contingente urbano - constituído de modo majoritário por valores alóctones, especialmente os europeus. E o próprio Hakim, com seu olhar de um apurado senso crítico, é quem avizinha a condição indígena à segregação socioespacial:

Esses atributos infames, vitupérios dirigidos a um homem pacato e quase invisível, eram lancetadas dirigidas também contra uma tradição ainda viva, que pulsava no coração dos bairros da periferia, no interior de habitações suspensas, açoitadas pelas chuvas (86).

Este é um momento capital da narrativa a fim de que se compreenda a porção ocupada pelo índio na geografia da cidade. Além de um espaço simbólico denegrido, somente digno de consideração, caso se manifeste a influência de alguém como Emilie, por exemplo, também foi destinado às populações indígenas um lugar de absoluto desprestígio na organização citadina. Dessa maneira, geograficamente, as personagens do romance podem ser discriminadas de modo simples, porém expressivo: na parte central da cidade, os Benemou, o genro do Comendador, um médico formado pela London School of Tropical Medicine, a família da matriarca libanesa, etc; à margem, distantes, enfiados em palafitas, contribuindo para a formação da Cidade Flutuante e de outros bairros paupérrimos, os miseráveis de Manaus -os excedentes da modernização de caráter conservador dos anos dourados da borracha.

Lobato Naturidade circula entre as personagens do centro e até angaria certo prestígio, por conta da amizade com Emilie. Em acréscimo a isso, há outro ponto a ser discutido capaz de evidenciar o reverso desse vínculo entre o indígena e a libanesa. Por meio de um compadrio às avessas, Lobato recomenda que a sobrinha busque emprego no sobrado da matriarca. Esta, além de agir como o esteio simbólico do curandeiro, dando-lhe a proteção necessária para percorrer ambientes refratários à sua presença, ainda é responsável por acolher Anastácia Socorro como empregada doméstica. No interior dessa intimidade 
tão extrema, reside uma evidente distinção do lugar social de cada um: sem Emilie, Naturidade não passaria de um charlatão ainda mais execrado pela comunidade manauara; sem Emilie, Naturidade não obteria uma colocação para a sobrinha. É, portanto, a imigrante libanesa quem dá as cartas; partem da sua vontade e do seu empenho os desígnios para índios e pobres.

Seguindo a linha sucessória de dependência à família-núcleo do romance, Anastácia Socorro ingressa como a empregada doméstica do sobrado. Vítima dos abusos e dos caprichos dos gêmeos, Anastácia apenas não tomou o mesmo caminho de outras empregadas, porque era pouco atraente e bastante resistente. No entanto, nem por isso a índia deixou de experimentar um martírio sob as ordens de Emilie. Entre essas duas personagens não havia uma relação marcada pela impessoalidade ou pela racionalidade, pressupostos elementares para um vínculo moderno entre empregador e empregado. Pelo contrário, correspondendo a costumes típicos da Manaus do século XX, em vez de um contato menos íntimo e, por conta disso, mais adequado a sistemas de trabalho atuais, sobrepunha-se à convivência de ambas um modelo de prática social gerido e justificado pelo próprio núcleo familiar. Ou seja, Socorro foi incorporada à dinâmica como se fosse um membro da família; entretanto, reside nessa mistura de afeto e trabalho a face mais violenta da cordialidade:

No meu íntimo [Hakim é o narrador], creio que deixei a família e a cidade também por não suportar a convivência estúpida com os serviçais. Lembro Dorner dizer que o privilégio aqui no norte não decorre apenas da posse de riquezas.

-Aqui reina uma forma estranha de escravidão - opinava Dorner. -A humilhação e a ameaça são o açoite; a comida e a integração ilusória à família do senhor são as correntes e golilhas (78).

O fotógrafo alemão, nesse breve comentário compartilhado com Hakim, evidencia a crueldade sobre a qual se estruturam as relações de trabalho no Norte, mais especificamente em Manaus. A prática a que ele se refere é bastante recorrente, e suas raízes, entranhadas na mentalidade dos grupos dirigentes, remontam aos tempos coloniais. Mulheres indígenas de aldeias do interior ou pertencentes a contingentes urbanizados possuem no trabalho doméstico uma das escassas alternativas de trabalho. Desgarradas de suas famílias, essas empregadas ingressam no seio de grupos abastados ainda adolescentes ou, até mesmo, crianças. A essas meninas, portanto, correspondem as tantas caboclas que tentaram servir a família de Emilie e também Anastácia Socorro, cujo amparo da matriarca se deu graças à indicação de Lobato Naturidade. Sob 
os desmandos e os caprichos dos patrões e seus filhos, Anastácia torna-se parte integrante do sobrado; como uma verdadeira coisa, a qual não cansasse, não possuísse desejos e desgostos, a indígena é submetida a uma rotina extenuante: trabalhos excessivos, agressões, castigos e humilhações das mais diversas naturezas. Contudo, nesse vínculo assumido entre a empregada e a patroa, existe um elemento de barganha: o privilégio. Por meio de um esforço (notado por Hakim), a matriarca age de modo afetuoso com a doméstica; além disso, os filhos da índia são considerados afilhados da libanesa. Neste ponto, observa-se o nervo de sustentação de uma relação empregatícia que é, em praticamente tudo, prejudicial à parte subalterna. Assim, embora perseguida pelos gêmeos e humilhada por Emilie, Socorro, para quem as chances de trabalho fora do sobrado não são variadas, tampouco em condições muito diversas que as experimentadas entre os libaneses, sente-se acolhida pela mãe de todos ao vê-la oferecendo a ocupação de amanuense para Expedito Socorro e o título de afilhado aos rebentos.

Em contrapartida, do outro lado dessa balança bastante desfavorável, situam-se as ações de Emilie. Para ela, o trabalho e o alimento oferecidos à empregada pertencem à dimensão da caridade; Anastácia Socorro, afilhados e sobrinhos, quando trabalham no interior do sobrado, são verdadeiros privilegiados. O peso da família nessa balança se intensifica e aprofunda a sua perversidade justamente na comida ofertada à empregada e a seus parentes: não lhes é permitida uma refeição semelhante à do resto da casa; doces e guloseimas são negados às domésticas. Concessões são feitas a Socorro, somente sob a proteção de Hakim:

Eu presenciava tudo calado, moído de dor na consciência, ao perceber que os fầmulos não comiam a mesma comida da família, e escondiam-se nas edículas ao lado do galinheiro, nas horas da refeição. A humilhação os transtornava até quando levavam a colher de latão à boca (76).

As frutas e as guloseimas eram proibidas às empregadas, e, cada vez que na minha presença Emilie flagrava Anastácia engolindo às pressas uma tâmara com caroço, ou mastigando um bombom de goma, eu me interpunha entre ambas e mentia à minha mãe, dizendo-lhe: fui eu que lhe ofereci o que sobrou da caixa de tâmaras que comi; assim, evitava um escândalo, uma punição ou uma advertência [...] (76).

Na esfera pública, Emilie é conhecida e louvada como a mãe de todos: comida e favores são ofertados aos moradores da Cidade Flutuante. Já na esfera privada, ela age de modo absolutamente diverso: as empregadas e seus 
parentes são de tal forma abjetos que a eles não cabe alimento semelhante ao dos patrões. Nessa atitude, observa-se a incoerência em que recai a tão pronunciada generosidade de Emilie; porém, tal incongruência se fundamenta justamente no embate entre público e privado. Ora, da porta do sobrado para fora, a matriarca é uma respeitosa senhora pertencente à elite local; por conta disso, a bondade é de seu interesse - a esmola não só lhe dignifica a imagem perante a cidade, como reitera a força e o alcance da sua influência; aos pobres, por sua vez, importa essa assistência da libanesa, pois ela é um dos poucos sujeitos em Manaus que lhes pode proporcionar algum rumo positivo na vida. Ao lado disso, no interior do sobrado, impera o costume da região - sob a condição de serviçais, indígenas e caboclos dedicam-se e submetem-se às extravagâncias e aos caprichos da família; em troca, apenas comida, e ruim.

O cimo da perfídia e da perversidade no relacionamento com a empregada doméstica se manifesta em um evento bastante peculiar dessa história. Quando a matriarca descobriu o parentesco entre Lobato Naturidade e Anastácia Socorro, esta "ficou mais íntima dos frequentadores da casa, e logrou a proteção de Emilie" (86), para ela "as tardes de ócio multiplicaram-se e as tarefas domésticas passaram a ser mais amenas" (86). Gerando revolta nos gêmeos, Anastácia, além de receber certo alívio em suas obrigações, passa a realizar as refeições na mesa da sala; um grande avanço nos hábitos da família - a índia dividia o mesmo espaço dos patrões e ainda experimentava da mesma comida. Entretanto, os irmãos inomináveis "nunca suportaram de bom grado" (86) essa inovação, e a "regalia súbita foi efêmera" (86):

Aquela mulher, sentada e muda, com o rosto rastreado de rugas, era capaz de tirar o sabor e o odor dos alimentos e de suprimir a voz e o gesto como se o seu silêncio ou a sua presença que era só silêncio impedisse o outro de viver. Sem que alguém lhe dissesse algo, Anastácia se esquivou dessa intimidade que causava repugnância nos meus irmãos, aflição em Emilie e uma discórdia generalizada na hora das refeições, um dos raros momentos em que a família hasteava a bandeira da paz (86-87).

Neste passo, é importante mostrar a maneira por que se formaliza o constrangimento ao qual a empregada é submetida ao redor da mesa dos libaneses. De modo bastante expressivo, o silêncio se interpõe na narrativa a fim de revelar o desprezo a que estão relegados os índigenas na sociedade manauara. Aos índios cabe tão somente o silêncio; diante de membros concernentes a estratos privilegiados, os integrantes da etnia autóctone reprimem 
a própria voz. A atitude tomada por essa personagem é mímese da condição dos índios amazônicos - desde os mais tenros dias da ocupação portuguesa, os indivíduos desse contingente étnico foram perseguidos e reprimidos em suas especificidades culturais sob o domínio do colonizador e dos religiosos. Ainda mais escorchante é a situação dos índios urbanizados, os quais, além de viverem a terrível mutilação identitária de não serem silvícolas, tampouco sujeitos reconhecidamente civilizados, são incorporados à sociedade manauara como empregados com quem se pode tudo: desde não remunerar pelo trabalho, controlar a comida, até agressões e estupros; tudo isso justificado pelas inconstâncias e pelos deslizes daqueles que ocupam posições distintas nessa relação vertical. Não é de modo algum desmotivado, portanto, que não somente Anastácia Socorro seja descrita por signos que remetem ao silêncio, mas também o tio, Lobato Naturidade, seja reconhecidamente um sujeito silencioso e fechado para si mesmo; assim como eles, Expedito Socorro, o terceiro membro dessa linha sucessória de submissão, é apenas referido na narrativa, sem que ao menos se saiba da própria voz nada além do trabalho prestado à matriarca; e o quarto e último integrante dessa genealogia, é a empregada que acolhe a narradora quando esta chega a Manaus - a índia se diz filha de Anastácia e afilhada de Emilie, após isso, conforme relata a irmã adotiva de Hakim, confina-se no seu "mutismo ancestral" (9).

Além dos traços sanguíneos, essas quatro personagens se ligam por formas semelhantes de dependência com a matriarca Emilie. Lobato Naturidade resgata o jovem libanês suicida; a partir daí, angaria proteção e prestígio da matriarca. Esse vínculo permite o ingresso de Anastácia Socorro como empregada do sobrado; apesar de submetida a uma condição cujas marcas são o desrespeito e a miserabilidade, a doméstica observa o sobrinho, Expedito Socorro, tornar-se o amanuense da mãe de todos, experiência que o credencia aos trabalhos no correio. Finalmente, a filha de Socorro também possui sua trajetória associada ao prestígio de Emilie: quando criança ajuda nos afazeres domésticos do sobrado; depois de adulta, permanece empregada doméstica e atrelada ao dia a dia da matriarca. Desse modo, imprime-se, nas existências desses quatro indígenas, o selo da circularidade: do primeiro ao último membro da genealogia, cada um deles é debitante do amparo da imigrante libanesa. 


\section{BIBLIOGRAFIA}

Araújo, Wagner dos Reis Marques. "Trabalho doméstico e servidão: trajetórias, gênero e identidade de mulheres indígenas em Manaus/AM". EDUCAmazônia 8/1 (2012): 8-25.

Hatoum, Milton. "Laços de Parentesco: Ficção e Antropologia". Raízes da Amazônia 1/1 (2004): 81-89.

Relato de um certo Oriente. São Paulo: Companhia das Letras, 2008.

Holanda, Sergio Buarque de. Raizes do Brasil. São Paulo: Companhia das Letras, 1995.

Miranda, Janira Sodré. "Mulheres indígenas, igreja e escravidão na América Portuguesa”. Em Tempo de Histórias 7 (2003): 1-16.

Rezende, Renato Cabral e Cerqueira, Rodrigo Soares. A cordialidade em Relato de um certo Oriente, de Milton Hatoum. Via Litterae 5/1 (2013): 239-256.

Ribeiro, Darcy. O povo brasileiro: a formação e o sentido do Brasil. São Paulo: Companhia das Letras, 2006.

Schwarz, Roberto. Um mestre na periferia do capitalismo. São Paulo: Duas Cidades, 2012. 